\title{
Ion and Acid-Base Balance in Three Species of Amazonian Fish during Gradual Acidification of Extremely Soft Water
}

\author{
Rod W. Wilson ${ }^{1,2, *}$ \\ Chris M. Wood ${ }^{1,3}$ \\ Rick J. Gonzalez ${ }^{1,4}$ \\ Marjorie L. Patrick ${ }^{1,5}$ \\ Harold L. Bergman ${ }^{1,6}$ \\ Annie Narahara, ${ }^{1,6}$ \\ Adalberto L. Val $^{1}$ \\ ${ }^{1}$ Laboratory of Ecophysiology and Molecular Evolution, \\ National Institute for Amazon Research, Alameda Cosme \\ Ferreira, 1756. 69.083-000 Manaus, AM, Brazil; ${ }^{2}$ Department \\ of Biological Sciences, Hatherly Laboratories, University of \\ Exeter EX4 4PS, United Kingdom; ${ }^{3}$ Department of Biology, \\ McMaster University, 1280 Main Street West, Hamilton, \\ Ontario L8S 4K1, Canada; ${ }^{4}$ Department of Biology, \\ University of San Diego, 5998 Alcalá Park, San Diego, \\ California 92110; ${ }^{5}$ Department of Ecology and Evolutionary \\ Biology, University of California, Irvine, California 92697; \\ ${ }^{6}$ Department of Zoology and Physiology, University of \\ Wyoming, Laramie, Wyoming 82071
}

Accepted 9/16/98

\begin{abstract}
Sensitivity to acid water was assessed in three species of Amazonian fish that encounter naturally acidic blackwaters to differing degrees in the wild: tambaqui (Colossoma macropomum), matrincha (Brycon erythropterum), and tamoatá (Hoplosternum littorale), in decreasing order of occurrence in blackwater. Fish were exposed to a graded reduction in water $\mathrm{pH}$, from $\mathrm{pH} 6$ to 5 to 4 to 3.5 , followed by return to $\mathrm{pH} 6$. Fish were exposed to each new $\mathrm{pH}$ for $24 \mathrm{~h}$. During these exposures, net transfers of ions $\left(\mathrm{Na}^{+}, \mathrm{K}^{+}, \mathrm{Cl}^{-}\right.$, and $\left.\mathrm{Ca}^{2+}\right)$ and acid-base equivalents to and from the external water were used as physiological indicators of acid tolerance. Exposure to $\mathrm{pH} 5$ had a minimal effect on net ion fluxes. Significant net losses of all ions (except $\mathrm{Ca}^{2+}$ ) were recorded in all three species during the first few hours of exposure to $\mathrm{pH}$ 4. However, ion balance was usually restored within $18 \mathrm{~h}$ at $\mathrm{pH}$ 4. Exposure to $\mathrm{pH} 3.5$ caused even greater
\end{abstract}

\footnotetext{
${ }^{\star}$ To whom correspondence should be addressed; e-mail: r.w.wilson@
} exeter.ac.uk.

Physiological and Biochemical Zoology 72(3):277-285. 1999. (C) 1999 by The University of Chicago. All rights reserved. 1522-2152/99/7203-9871\$03.00 ion losses in all three species and proved to be acutely lethal to tamoatá. Matrincha sustained irreversible physiological damage at $\mathrm{pH} 3.5$, as ion fluxes did not recover following return to $\mathrm{pH} 6$ and there was some mortality. Tambaqui suffered the least ionoregulatory disturbances at $\mathrm{pH} 3.5$ and was the only species to make a full recovery on return to $\mathrm{pH}$ 6. In all species, there was a tendency for ammonia excretion to increase at low water $\mathrm{pH}$, but even at $\mathrm{pH} 3.5$, there was no significant net uptake of acid from the water. Overall, there was a strong relationship between the magnitude of ionic disturbances and the lethality of exposure to low $\mathrm{pH}$. The relative insensitivity of the ionoregulatory system of tambaqui to low $\mathrm{pH}$ indicates that this is a feature of fish native to blackwater systems rather than one that is common to all Amazon fish.

\section{Introduction}

The Rio Negro is a major tributary of the Amazon River and is characterized by its deeply colored appearance (often referred to as "blackwater") and paucity of dissolved salts. Typically, water conductivity is low $\left(<10 \mu \mathrm{S} \mathrm{cm}^{-1}\right)$ due to the nutrientpoor jungle soils from which it arises (Furch 1984). For example, concentrations of sodium and calcium rarely exceed 20 and $10 \mu \mathrm{mol} \mathrm{L}^{-1}$, respectively. The Rio Negro and other blackwater systems of the Amazon basin are also characterized by their acidity. This is due to poor buffering capacity and the vast input of organic acids from decaying plant material in the surrounding tropical rain forest. The acidity reaches its peak in forest streams near the river source $(\mathrm{pH} 3.5-4.5$; Walker and Henderson 1996), but even the average $\mathrm{pH}$ for water in the main Rio Negro is low ( $\mathrm{pH} 5.1 \pm 0.6$; Furch 1984). Other tributaries of the Amazon River drain less nutrient-poor water, have a higher conductivity ( $>50 \mu \mathrm{S} \mathrm{cm}{ }^{-1}$ ) and ion concentrations $\left(\mathrm{Na}\right.$ and $\left.\mathrm{Cl}>100 \mu \mathrm{mol} \mathrm{L}{ }^{-1}\right)$, and are not acidic $(\mathrm{pH} \sim$ 6.9; Furch 1984). These are often referred to as "whitewater" systems because of the amount of suspended solids present.

Our current understanding of the physiology of ion regulation in freshwater fish has been developed primarily from studies on teleosts from the Northern Hemisphere. In these species, it is well established that the combination of dilute water and low $\mathrm{pH}$ causes ionoregulatory dysfunction as a result of inhibition of active ion uptake and acceleration of diffusive ion losses at the gills (McDonald and Wood 1981; Gonzalez and Dunson 1987, 1989; Wood 1989). On the basis of this 
pattern, one would expect conditions within the dilute and acidic blackwaters of the Rio Negro to represent a relatively hostile environment for freshwater fish in terms of ion regulation. However, both the whitewater and blackwater regions of the Amazon support a remarkable abundance and diversity of fish life (Val and Almeida-Val 1995).

In a previous article, we assessed the ionoregulatory responses of several species of Rio Negro fish following acute exposure to pH 3.5 (Gonzalez et al. 1998). All these species, endemic to blackwater, had remarkable acid tolerance and suffered only modest ionoregulatory disturbances compared with Northern Hemisphere fish. Our study sought to compare the acid tolerance of three Amazon species that naturally encounter acidic blackwaters to differing degrees in the wild. These range from fish that normally live only in whitewater to fish that are seasonally resident in blackwater (Val and Almeida-Val 1995). Tamoatá (Hoplosternum littorale), heavily armored catfish, are not naturally found within the blackwater systems but are an interesting comparison because they are extremely tolerant of a number of other environmental variables, such as low oxygen and high hydrogen sulfide (Brauner et al. 1995). Matrincha (Brycon erythropterum) spend the majority of their life in the whitewaters of the Rio Branco but move through the blackwaters of the Rio Negro during their annual migration to spawning grounds (the meeting of the whitewater and blackwater rivers of the Rio Solimoes and Rio Negro; Zanibon-Filho 1985). Tambaqui (Colossoma macropomum) move seasonally between whitewater and blackwater rivers and enter extremely dilute, acidic areas of flooded jungle to feed during the rainy season (Araujo-Lima and Goulding 1997).

If tolerance to low $\mathrm{pH}$ is a general feature of Amazonian fish rather than a characteristic of fish found within the blackwater systems, then one would not expect to find any differences between these species in terms of their physiological responses to low $\mathrm{pH}$. This has been assessed by exposing the three species to graduated reductions in external pH (from pH 6 to 5 to 4 to 3.5), maintaining fish for $24 \mathrm{~h}$ at each new $\mathrm{pH}$. Ion and acid-base regulation are intimately linked in freshwater fish because of (1) the nature of the counterions involved in $\mathrm{Na}^{+}$ and $\mathrm{Cl}^{-}$uptake at the gills and (2) the influence of differential cation and anion effluxes on strong ion difference (Wood and Goss 1990). It was therefore decided to use the net fluxes of a variety of ions $\left(\mathrm{Na}^{+}, \mathrm{K}^{+}, \mathrm{Cl}^{-}\right.$, and $\left.\mathrm{Ca}^{2+}\right)$ and acid-base equivalents (as calculated from the ammonia and titratable acid fluxes) as physiological indicators of acid tolerance in these three Amazon species.

\section{Material and Methods}

Animals

Experiments were carried out at the Laboratory of Ecophysiology and Molecular Evolution, National Institute for Amazon Research (Instituto Nacional de Pesquisas da Amazonia
[INPA]), Manaus, Brazil, in November-December 1995. The three species of fish used, tambaqui (Colossoma macropomum), matrincha (Brycon erythropterum), and tamoatá (Hoplosternum littorale), were obtained from commercial aquaculture (the Amazon Fish Farm near Itacoatiara City, ca. 200 km from Manaus) in November 1995. Fish had been raised here in large, shallow outdoor ponds at $25^{\circ}-37^{\circ} \mathrm{C}$ with $\mathrm{O}_{2}$ saturation close to $100 \%$. The composition of the water flushing the ponds varied periodically between circumneutral whitewater $(\mathrm{pH} 7.5)$ and acidic groundwater ( $\mathrm{pH} 4.0$; similar to dilute blackwater). Thus, although these fish had experienced a range of water ion and $\mathrm{pH}$ levels, all three species had the same history before delivery at INPA, Manaus.

On arrival in Manaus, all fish were held for 7-14 d before experiments in INPA groundwater with the following physicochemical composition (ion concentrations expressed in $\mu \mathrm{mol}$ $\mathrm{L}^{-1}$ ): $\mathrm{pH}$ 6.0-6.5 (following aeration to atmospheric $\mathrm{PCO}_{2} \sim$ $0.3 \mathrm{mmHg}) ; \mathrm{Na}^{+}, 15 ; \mathrm{Cl}^{-}, 16 ; \mathrm{K}^{+}, 9 ; \mathrm{Ca}^{2+}, 9 ; \mathrm{Mg}^{2+}, 2 ; \mathrm{NO}_{3}^{-}$, 37; $\mathrm{SO}_{4}^{2-}, 5$; total phosphate, 1 ; and water alkalinity, 130 (as $\mathrm{CaCO}_{3}$ ). Additional calcium was added to this groundwater (as calcium nitrate) so that all experiments were carried out in an identical total $\mathrm{Ca}^{2+}$ concentration of $20 \mu \mathrm{mol} \mathrm{L}{ }^{-1}$, which was compatible with survival of both blackwater and whitewater fish while still being extremely soft. Dissolved organic carbon concentration was $2.05 \mathrm{mg} \mathrm{L}^{-1}$, and temperature was $28^{\circ}-30^{\circ} \mathrm{C}$. This very dilute water, close to natural blackwater apart from its lower organic content, was used in all experiments. Fish were not fed during the holding period or during experiments.

\section{Experimental Protocol}

Flux chambers were made from modified 20-L plastic water bottles in the case of matrincha $(696 \pm 72 \mathrm{~g})$ and $10-\mathrm{L}$ or $5-$ $\mathrm{L}$ plastic carboys in the case of tambaqui $(139 \pm 13 \mathrm{~g})$ and tamoatá (136 $\pm 13 \mathrm{~g})$, respectively. All fish (six of each species) were transferred from holding tanks to individual flux chambers and left overnight to recover from handling stress before experiments. Each flux chamber was supplied with water (flow rates $\left.>500 \mathrm{~mL} \mathrm{~min}^{-1}\right)$ from a recirculating system $(700,700$, and $70 \mathrm{~L}$ total volume for the three species, in descending order of chamber size), and water in each chamber was aerated at all times. To prevent the excessive accumulation of excretory products, such as ammonia, 50\% water changes were performed daily for these recirculating systems.

On the first day of the experiment, water $\mathrm{pH}$ was unaltered $(\mathrm{pH} \sim 6)$ to act as a control period. Net ion and acid-base fluxes were measured twice each day, after 1 and $18 \mathrm{~h}$ of exposure to that particular $\mathrm{pH}$. During the first flux measurement of each day, water supply to each chamber was turned off and $20-\mathrm{mL}$ water samples were taken immediately and then after either 1 $\mathrm{h}$ (matrincha and tamoatá) or $2 \mathrm{~h}$ (tambaqui). Aeration ensured mixing and the maintenance of $\mathrm{Po}_{2}$ close to air saturation 
during the periods of closure. Flow was then returned to each chamber, and 16-17 h later, a second flux measurement was made. On day 2 , the water in the recirculating system was gradually acidified over a period of $3 \mathrm{~h}$ to $\mathrm{pH} 5$ with $\mathrm{H}_{2} \mathrm{SO}_{4}$. Flux measurements were then made 1 and $18 \mathrm{~h}$ after this new $\mathrm{pH}$ had been reached. On days 3 and 4, the water $\mathrm{pH}$ was lowered to $\mathrm{pH} 4$ and 3.5, respectively, and the same flux protocols were repeated. On day 5 , the water $\mathrm{pH}$ was then returned to $\mathrm{pH} 6.5$ (by a combination of water changes and addition of $\mathrm{KOH}$ ), and the same flux protocol was repeated as a "recovery" flux measurement. In the case of tamoatá only, the $\mathrm{pH} 5$ step was omitted; that is, $\mathrm{pH}$ was changed from 6 directly to 4 on day 2. This was due to time limitations and the prior knowledge that $\mathrm{pH} 5$ had negligible effects on the other two species. At the end of the recovery flux, all fish were removed from the chambers and weighed.

\section{Analytical Techniques}

The $\mathrm{pH}$ of water samples was measured using a $\mathrm{pH}$ electrode and meter (Orion). Water cations $\left(\mathrm{Na}^{+}, \mathrm{K}^{+}\right.$, and $\left.\mathrm{Ca}^{2+}\right)$ were measured by flame photometry. Water chloride concentration was measured using a modified colorimetric assay (Zall et al. 1956). Water total ammonia concentration was measured using a micromodified version of the salicylate-hypochlorite method of Verdouw et al. (1978). The change in titratable alkalinity in water samples from the beginning and end of fluxes was measured by titrating each $10-\mathrm{mL}$ sample to exactly $\mathrm{pH} 3.2$ with $0.02 \mathrm{~N} \mathrm{HCl}$, with continuous aeration of samples during titration to ensure mixing and removal of $\mathrm{CO}_{2}$. The end point $\mathrm{pH}$ of 3.2, sufficiently below the lowest experimental water $\mathrm{pH}(4)$, was chosen so that all titratable alkalinity values were directly comparable.

Net flux rates were calculated using the following equation:

$$
J_{\text {net }}^{x}=\left[\left([X]_{i}-[X]_{f}\right) \times V\right] /(M \times t)
$$

where $[X]_{i}$ and $[X]_{f}$ are the chamber water ion concentrations at the beginning and end of the flux period, respectively; $V$ is the volume of water in the chamber (after the initial sample was taken); $M$ is the mass of the fish (kg); and $t$ is the duration of the flux period $(\mathrm{h})$. Titratable acid flux rates $\left(J_{\mathrm{TA}}\right)$ were calculated from the above equation using titratable alkalinity measurements, but the initial and final values were reversed to achieve acid instead of base fluxes. Net acidic equivalent $\left(\mathrm{H}^{+}\right)$ flux $\left(J_{\mathrm{H}^{+}}^{\mathrm{net}}\right)$ was determined as the sum, signs considered, of $J_{\mathrm{TA}}$ and $J_{\mathrm{Amm}}$, as described in McDonald and Wood (1981). It should be pointed out that $J_{\mathrm{H}^{+}}^{\text {net }}$ can result from the movement of any of the following: $\mathrm{H}^{+}, \mathrm{NH}_{4}^{+}, \mathrm{HCO}_{3}^{-}$, or $\mathrm{OH}^{-}$. While it is not possible to distinguish between these forms, $\mathrm{H}^{+}$and $\mathrm{NH}_{4}^{+}$excretion and $\mathrm{HCO}_{3}^{-}$and $\mathrm{OH}^{-}$uptake are all equivalent in terms of the acid-base status of the fish. For all fluxes, a negative sign represents a net loss by the animal, and positive represents a net gain.

\section{Statistical Analysis}

Data have been expressed as means \pm SE $(N)$, where $N=$ number of fish. Each fish was used as its own control, so net fluxes at the different $\mathrm{pH}$ treatments were compared using a Student's two-tailed paired $t$-test at the $5 \%$ level of significance. Values at each $\mathrm{pH}$ treatment were compared with the appropriate control values (either 1 or $18 \mathrm{~h}$ of exposure). Bonferroni correction for multiple comparisons was applied (Nemenyi et al. 1977).

\section{Results}

\section{$\mathrm{Net} \mathrm{Na}^{+}$and $\mathrm{Cl}^{-}$Fluxes}

All three species were approximately in ion balance with respect to $\mathrm{Na}$ and $\mathrm{Cl}$ during the control flux periods at $\mathrm{pH} 6$ (i.e., net fluxes for these ions were within $\sim 50 \mu \mathrm{mol} \mathrm{kg}^{-1} \mathrm{~h}^{-1}$ of zero; Figs. 1, 2). Exposure to $\mathrm{pH} 5$ had no significant effect on either $\mathrm{Na}^{+}$or $\mathrm{Cl}^{-}$fluxes in the matrincha and tambaqui. Catfish were not exposed to $\mathrm{pH}$ 5. Exposure to $\mathrm{pH} 4$ for $1 \mathrm{~h}$ produced significant net losses of $\mathrm{Na}^{+}$and $\mathrm{Cl}^{-}$in all three species (mean fluxes ranged from $-176 \pm 27$ to $-319 \pm 14 \mu \mathrm{mol} \mathrm{kg}^{-1} \mathrm{~h}^{-1}$ ). By $18 \mathrm{~h}$ of exposure to $\mathrm{pH} 4$, net $\mathrm{Na}^{+}$or $\mathrm{Cl}^{-}$fluxes had recovered to within $100 \mu \mathrm{mol} \mathrm{kg}{ }^{-1} \mathrm{~h}^{-1}$ of zero in all three species, although the net $\mathrm{Cl}^{-}$loss in matrincha was still significantly lower than the relevant control period (Fig. 2).

Exposure to $\mathrm{pH} 3.5$ produced the most dramatic differential between the three species. Tamoatá suffered very large losses of both $\mathrm{Na}^{+}$and $\mathrm{Cl}^{-}$after just $1 \mathrm{~h}(-894 \pm 41$ and $-633 \pm$ $46 \mu \mathrm{mol} \mathrm{kg}{ }^{-1} \mathrm{~h}^{-1}$, respectively), and none survived until the 18-h flux period. Assuming that total body $\mathrm{Na}$ and $\mathrm{Cl}$ contents are similar to those of other freshwater fish (e.g., 33 and 29 $\mu \mathrm{mol} \mathrm{g}^{-1}$, respectively, in soft-water-acclimated rainbow trout; Wilson et al. 1994), these flux rates would represent net losses equivalent to $65 \%$ and $52 \%$ of whole body $\mathrm{Na}$ and $\mathrm{Cl}$ stores, respectively, if continued for $24 \mathrm{~h}$. Matrincha were more tolerant of $\mathrm{pH} 3.5$, with net losses of $\mathrm{Na}^{+}$and $\mathrm{Cl}^{-}$that were only $66 \%$ and $75 \%$, respectively, of those for tamoatá during the first hour. The magnitude of these negative fluxes was reduced by about $40 \%$ after $18 \mathrm{~h}$ at $\mathrm{pH} 3.5$, but matrincha were still suffering significant net losses of both $\mathrm{Na}^{+}$and $\mathrm{Cl}^{-}$at this time. There was some delayed mortality in the matrincha on returning to $\mathrm{pH} 6$, with only five and then two fish surviving after 1 and $18 \mathrm{~h}$ of the recovery period, respectively.

Tambaqui suffered the least ionoregulatory disturbances at $\mathrm{pH} 3.5$ with net $\mathrm{Na}^{+}$and $\mathrm{Cl}^{-}$fluxes after $1 \mathrm{~h}$ that were only $42 \%$ and $43 \%$, respectively, of those for tamoatá during the 


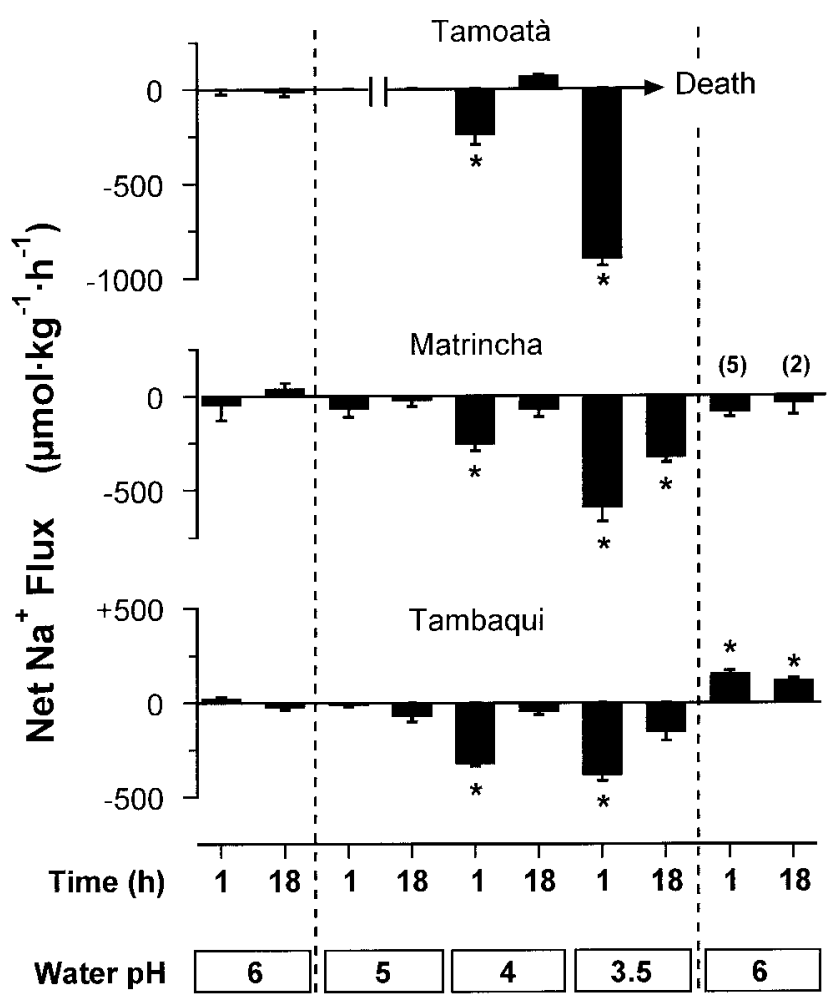

Figure 1. Effect of graduated water $\mathrm{pH}$ changes on net $\mathrm{Na}^{+}$fluxes in three species of Amazonian fish: tamoatá (Hoplosternum littorale), matrincha (Brycon erythropterum), and tambaqui (Colossoma macropomum). Fish were exposed to each new $\mathrm{pH}$ for $24 \mathrm{~h}$, and fluxes were measured after 1 and $18 \mathrm{~h}$ of exposure to each new pH level. Bars represent means \pm SE. $N=6$ fish at the start for all three species. No tamoatá survived beyond the first hour of exposure to $\mathrm{pH} 3.5$. Some mortalities were also observed in the matrincha during the recovery period at pH 6 (numbers in parentheses indicate number of surviving fish). Asterisks indicate numbers are significantly different from the appropriate (either 1- or 18-h) control flux at $\mathrm{pH} 6$.

same period. A substantial recovery of these ion fluxes was observed after $18 \mathrm{~h}$ at $\mathrm{pH} 3.5$; indeed, net $\mathrm{Na}^{+}$fluxes were not significantly different from the appropriate control period in tambaqui. On return to $\mathrm{pH} 6$, net $\mathrm{Na}^{+}$fluxes rapidly reversed to positive values that were significantly higher than the control

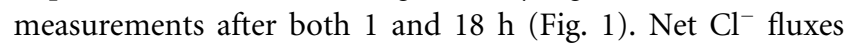
followed a similar trend though were not significantly above the control values.

\section{Net $K^{+}$Fluxes}

Net $\mathrm{K}^{+}$fluxes were in or close to equilibrium under control conditions ( $\mathrm{pH} 6)$ and were unaffected by exposure to $\mathrm{pH} 5$

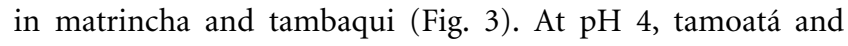

tambaqui experienced significant net losses of $\mathrm{K}^{+}$after both 1 and $18 \mathrm{~h}$ of exposure. This effect was delayed until the 18-h flux measurement in matrincha. This pattern and magnitude of net $\mathrm{K}^{+}$losses were repeated in the tambaqui when water $\mathrm{pH}$ was decreased further to 3.5 , although net flux after $18 \mathrm{~h}$ was not significantly different from the control period in tambaqui. However, exposure to $\mathrm{pH} 3.5$ caused a much greater stimulation of net $\mathrm{K}^{+}$losses in the tamoatá and matrincha. Net losses were more than tripled after just $1 \mathrm{~h}$ in the tamoatá, and all fish were dead before the 18 -h flux at this $\mathrm{pH}$. No recovery of $\mathrm{K}^{+}$ fluxes was apparent in the matrincha, even after $18 \mathrm{~h}$ at $\mathrm{pH}$

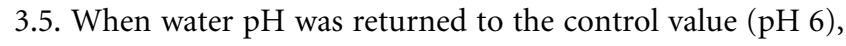
tambaqui completely recovered $\mathrm{K}^{+}$balance, whereas the surviving matrincha suffered a continuation of large net $\mathrm{K}^{+}$losses,

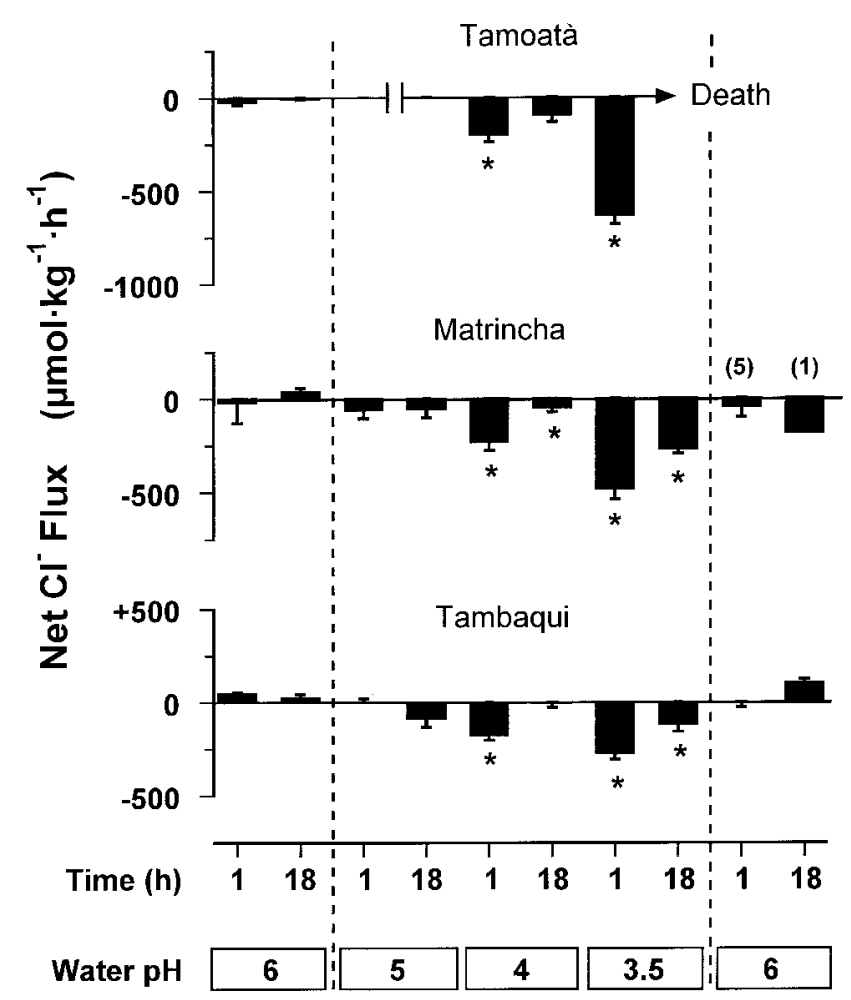

Figure 2. Effect of graduated water $\mathrm{pH}$ changes on net $\mathrm{Cl}^{-}$fluxes in three species of Amazonian fish: tamoatá (Hoplosternum littorale), matrincha (Brycon erythropterum), and tambaqui (Colossoma macropomum). Fish were exposed to each new $\mathrm{pH}$ for $24 \mathrm{~h}$, and fluxes were measured after 1 and $18 \mathrm{~h}$ of exposure to each new $\mathrm{pH}$ level. Bars represent means \pm SE. $N=6$ fish at the start for all three species. No tamoatá survived beyond the first hour of exposure to $\mathrm{pH}$ 3.5. Some mortalities were also observed in the matrincha during the recovery period at pH 6 (numbers in parentheses indicate number of surviving fish). Asterisks indicate numbers are significantly different from the appropriate (either 1- or 18-h) control flux at $\mathrm{pH} 6$. 


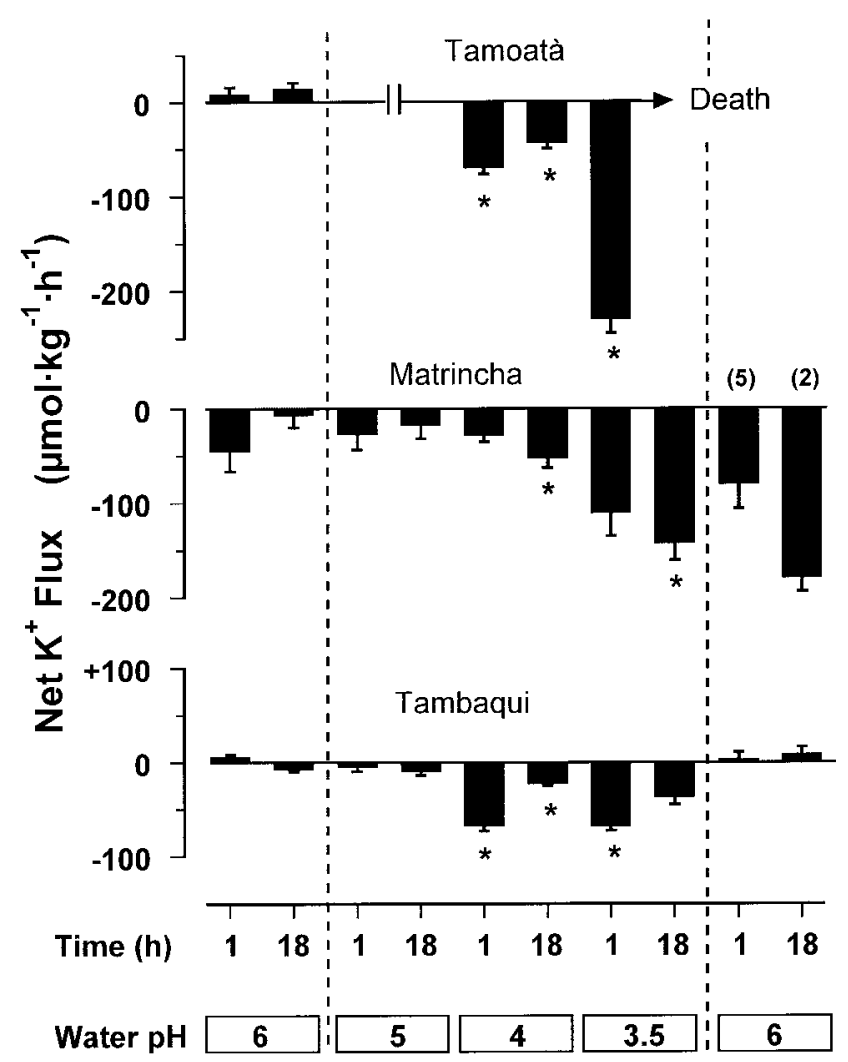

Figure 3. Effect of graduated water $\mathrm{pH}$ changes on net $\mathrm{K}^{+}$fluxes in three species of Amazonian fish: tamoatá (Hoplosternum littorale), matrincha (Brycon erythropterum), and tambaqui (Colossoma macropomum). Fish were exposed to each new $\mathrm{pH}$ for $24 \mathrm{~h}$, and fluxes were measured after 1 and $18 \mathrm{~h}$ of exposure to each new $\mathrm{pH}$ level. Bars represent means \pm SE. $N=6$ fish at the start for all three species. No tamoatá survived beyond the first hour of exposure to $\mathrm{pH}$ 3.5. Some mortalities were also observed in the matrincha during the recovery period at $\mathrm{pH} 6$ (numbers in parentheses indicate number of surviving fish). Asterisks indicate numbers are significantly different from the appropriate (either 1- or 18-h) control flux at pH 6.

although these were not significant because of the declining number of fish.

\section{Net $\mathrm{Ca}^{2+}$ Fluxes}

Unlike the patterns observed for the above monovalent ions (Figs. 1-3), there was no obvious trend for increasingly negative net $\mathrm{Ca}^{2+}$ fluxes as $\mathrm{pH}$ was gradually reduced (Fig. 4). Significant net losses of $\mathrm{Ca}^{2+}$ were observed during exposure to $\mathrm{pH} 5$ in the tambaqui and at pH 3.5 in the tamoatá and tambaqui. However, these losses did not appear to be proportional to external acidity, and, relative to the monovalent ion fluxes, absolute rates were very low after $1 \mathrm{~h}$ at $\mathrm{pH} 3.5$, even in the tamoatá, which died within hours of this measurement.

\section{Net Acid-Base Fluxes}

There was a tendency for ammonia excretion $\left(J_{\text {Amm }}\right.$; the hatched bars in Fig. 5) to increase in all three species during the graduated reduction in external acidity (Fig. 5). This trend reached its peak after $1 \mathrm{~h}$ at $\mathrm{pH} 3.5$ when ammonia excretion was at least double the control rate in all three species. The effect of $\mathrm{pH}$ on titratable acid fluxes $\left(J_{\mathrm{TA}}\right.$; the upward open bars in Fig. 5) was not so consistent. Exposure to both pH 5 and 4 for 18 h significantly reduced $J_{\mathrm{TA}}$ in matrincha, whereas 1-h exposure to $\mathrm{pH} 3.5$ caused a large increase in $J_{\mathrm{TA}}$ in the tamoatá. The $J_{\mathrm{TA}}$ was unaffected by $\mathrm{pH}$ in the tambaqui. Under control con-

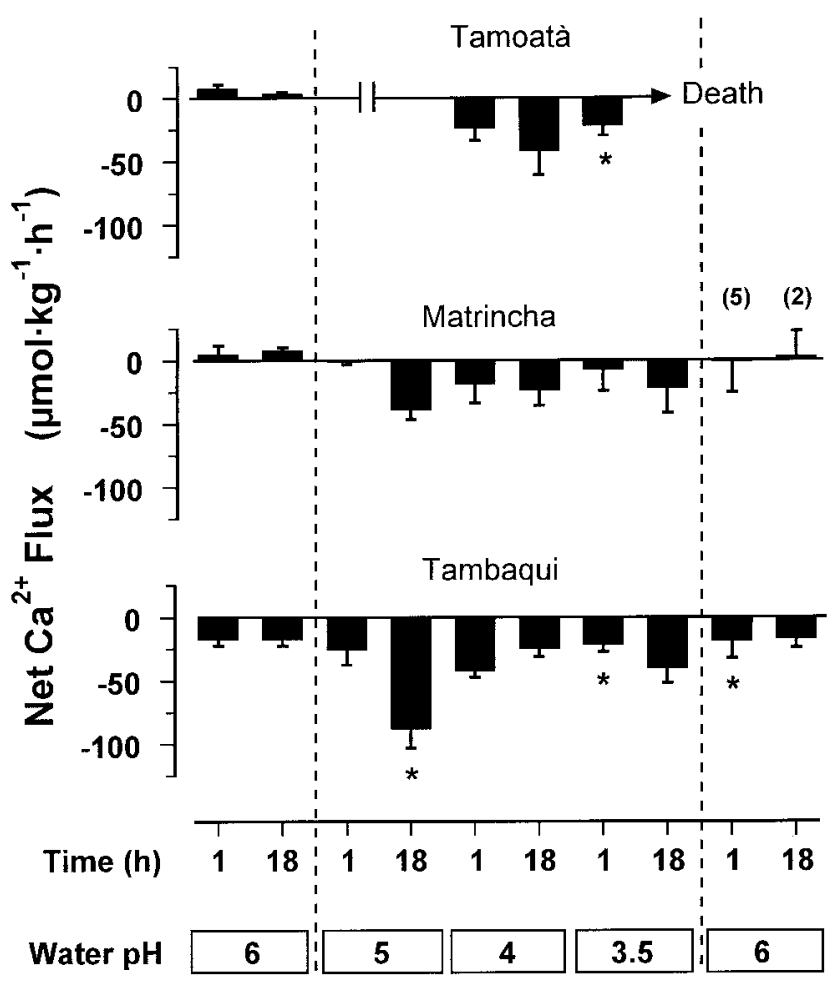

Figure 4. Effect of graduated water $\mathrm{pH}$ changes on net $\mathrm{Ca}^{2+}$ fluxes in three species of Amazonian fish: tamoatá (Hoplosternum littorale), matrincha (Brycon erythropterum), and tambaqui (Colossoma macropomum). Fish were exposed to each new $\mathrm{pH}$ for $24 \mathrm{~h}$, and fluxes were measured after 1 and $18 \mathrm{~h}$ of exposure to each new $\mathrm{pH}$ level. Bars represent means \pm SE. $N=6$ fish at the start for all three species. No tamoatá survived beyond the first hour of exposure to $\mathrm{pH} 3.5$. Some mortalities were also observed in the matrincha during the recovery period at $\mathrm{pH} 6$ (numbers in parentheses indicate number of surviving fish). Asterisks indicate numbers are significantly different from the appropriate (either 1- or 18-h) control flux at $\mathrm{pH} 6$. 


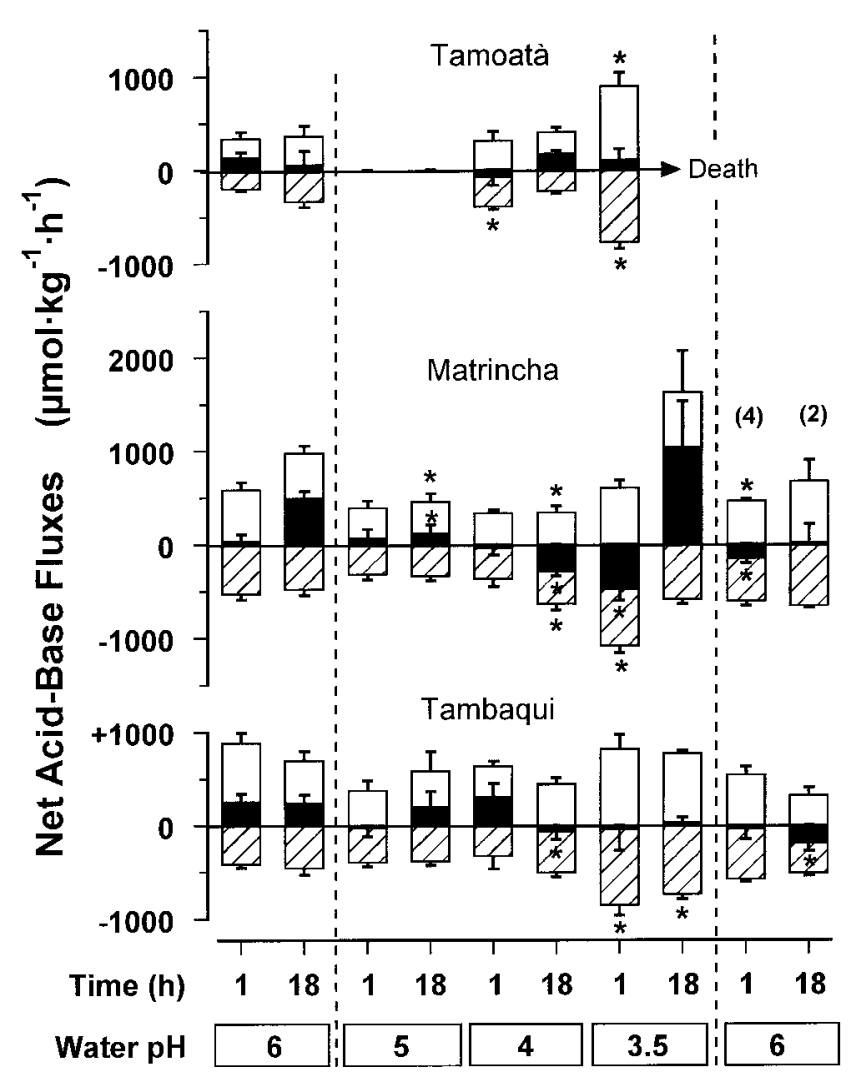

Figure 5. Effect of graduated water $\mathrm{pH}$ changes on acid-base fluxes in three species of Amazonian fish: tamoatá (Hoplosternum littorale), matrincha (Brycon erythropterum), and tambaqui (Colossoma macropomum). Fish were exposed to each new $\mathrm{pH}$ for $24 \mathrm{~h}$, and fluxes were measured after 1 and $18 \mathrm{~h}$ of exposure to each new $\mathrm{pH}$ level. Hatched bars represent total ammonia fluxes; open bars represent titratable acid fluxes $\left(J_{\mathrm{TA}}\right)$; solid bars represent net acidic equivalent fluxes. Bars represent means \pm SE. $N=6$ fish at the start for all three species. No tamoatá survived beyond the first hour of exposure to $\mathrm{pH}$ 3.5. Some mortalities were also observed in the matrincha during the recovery period at $\mathrm{pH} 6$ (numbers in parentheses indicate number of surviving fish). Asterisks indicate numbers are significantly different from the appropriate (either 1- or 18-h) control flux at $\mathrm{pH} 6$.

ditions, all species generally had positive net acidic equivalent fluxes $\left(J_{\mathrm{H}^{+}}^{\text {net }}\right.$; the solid bars in Fig. 5), that is, net acid uptake or base excretion. This is likely due to the herbivorous nature and recent dietary history of the three species, which would lead to base loading as a result of bicarbonate generation during the oxidation of organic acids (Hills 1973).

Interestingly, the only significant effects of increasing the water acidity were to reverse these to negative values (i.e., to net acid excretion) in matrincha at $\mathrm{pH} 4$ after $1 \mathrm{~h}$ at $\mathrm{pH} 5$ and during the recovery at $\mathrm{pH} 6$ and in the tambaqui at $\mathrm{pH} 4$ and during the recovery period $(\mathrm{pH} 6)$. Although the matrincha appeared to have a large net uptake of acidic equivalents after $18 \mathrm{~h}$ at $\mathrm{pH}$, this was not statistically significant.

\section{Discussion \\ Species Sensitivity to Low $p H$}

The relative sensitivity of the three species to low external $\mathrm{pH}$ was as predicted based on the degree of their normal occurrence in naturally acidic blackwaters in the Amazon basin. No mortality was observed in the tambaqui, which are found in both blackwater and whitewater areas. Matrincha experience blackwater in the wild but only pass through the main (least acidic) channel of the Rio Negro during spawning migrations; only two out of the six matrincha survived the entire exposure regime in these experiments. The tamoatá, resident mainly in whitewater rivers, were the least acid tolerant, being unable to survive more than a few hours at $\mathrm{pH} 3.5$. Although this comparison is based on only three species, the data here suggest that acid tolerance is related to life in blackwater areas rather than being a characteristic of all fish of the Amazon. The extremely high tolerance of tamoatá to other noxious environments, such as low oxygen and high hydrogen sulfide (Brauner et al. 1995; Val and Almeida-Val 1995), was not paralleled by a high tolerance to low $\mathrm{pH}$. However, this is perhaps not surprising and probably reflects differential mechanisms of toxicity for low $\mathrm{pH}$ (ionoregulation) and these other variables (gas transport).

\section{Acid Toxicity and Ionoregulatory Failure}

In general, there was a strong relationship between the magnitude of ion losses for $\mathrm{Na}, \mathrm{Cl}$, and $\mathrm{K}$ and the toxicity of exposure to low $\mathrm{pH}$ (Figs. 1-3). In the tamoatá and matrincha, net losses of the three monovalent ions became excessive at the lowest $\mathrm{pH}$, whereas tambaqui suffered the least in terms of net ion losses and made a full recovery when returned to $\mathrm{pH} 6$. This fits with the concept that acid toxicity is exerted primarily through its effect on ionoregulatory systems in the gills of freshwater fish (McDonald 1983; Wood 1989; Reid 1995). In contrast to the monovalent ions, net $\mathrm{Ca}^{2+}$ fluxes were not overtly affected by low $\mathrm{pH}$. This is also true of nonacidophilic species from the Northern Hemisphere exposed to milder pH's (Höbe et al. 1984; Audet et al. 1988; Verbost et al. 1992).

The exceptional tolerance of tambaqui to low $\mathrm{pH}$ during our flux experiments was emphasized in the parallel study by Wood et al. (1998); cannulated tambaqui exposed to a similar graded $\mathrm{pH}$ regime experienced no significant disturbances in blood parameters relating to ion regulation, gas transport, or acidbase balance down to $\mathrm{pH}$ 4. However, there appears to be a threshold somewhere between $\mathrm{pH} 3.5$ and 3 at which tambaqui 
reach their limit for physiological recovery. Wood et al. (1998) exposed tambaqui to $\mathrm{pH} 3.0$ rather than 3.5 during the last day of acid exposure and observed a severe stress response (elevated plasma cortisol, glucose, and ammonia levels and reduced plasma ions) and $42 \%$ mortality. In cannulated tambaqui, it was clear that permanent damage to their ionoregulatory systems had been sustained at $\mathrm{pH} 3.0$ because several variables including plasma ion levels did not recover following return to $\mathrm{pH} 6$.

The elevation of ammonia excretion at the lowest $\mathrm{pH}$ is indicative of a generalized stress response in which cortisol can promote proteolysis (Anderson et al. 1991; van der Boon et al. 1991). This would raise circulating ammonia concentrations, as found in our parallel study on cannulated tambaqui (Wood et al. 1998). Despite the very large $\mathrm{H}^{+}$gradient from water to blood when exposed to $\mathrm{pH} 3.5$, the net flux of acidic equivalents remained at essentially zero in the tambaqui. This agrees with the absence of any internal acid-base disturbances in cannulated tambaqui, even after $24 \mathrm{~h}$ at $\mathrm{pH} 3.0$ (Wood et al. 1998). Acidbase disturbances are similarly lacking in salmonids exposed to low $\mathrm{pH}$, provided the water calcium concentration is sufficiently low (Wood 1989). However, such measurements have not been made in salmonids exposed to pH's lower than 4 . The complete absence of any changes in the blood acid-base status in the tambaqui, even at $\mathrm{pH} \mathrm{3}$, is therefore still impressive. Possible explanations for this and the role of external calcium in modulating acid-base fluxes across the gills are discussed in more detail in the article by Wood et al. (1998).

It is perhaps not surprising that, qualitatively at least, acid water affects blackwater residents in a similar manner to nonacidophilic Northern Hemisphere fish; that is, ionoregulation is the primary target of acid toxicity. The difference is therefore mainly quantitative, with tambaqui having a threshold for acute toxicity approximately $1 \mathrm{pH}$ unit lower than that for salmonids (Fromm 1980; Wood and McDonald 1982; Reid 1995). This represents a 10 -fold higher $\mathrm{H}^{+}$ion concentration, which emphasizes the exceptional acid tolerance of the tambaqui.

\section{Acclimatory Responses during Gradual Exposure to Low $p H$}

The gradual water acidification regime employed in our study is probably more relevant for fish like tambaqui than acute transfer to low $\mathrm{pH}$. These fish are most likely to experience changes in water $\mathrm{pH}$ that are gradual and progressive if they swim from whitewater to blackwater areas and then into the most acidic forest streams.

The use of a graduated water acidification regime in our study clearly reduced the severity of ion losses in tambaqui. By comparison, tambaqui held in the same water conditions as used in our study but transferred directly from $\mathrm{pH} 6$ to 3.5 for $1 \mathrm{~h}$ suffered two- to threefold greater losses of $\mathrm{Na}^{+}$and $\mathrm{Cl}^{-}$ (Wood et al. 1998). This difference indicates that compensatory mechanisms were initiated during the gradual exposure, which allowed a substantial improvement in their ability to overcome further reductions in $\mathrm{pH}$. The induction of such compensatory responses must be quite rapid because tambaqui had largely regained control of their net ion fluxes within $18 \mathrm{~h}$ of exposure to each new acidic $\mathrm{pH}$.

Similar reductions in the degree of physiological disturbances have been seen in brown trout, carp, and tilapia when gradually rather than abruptly exposed to milder acidities (Stuart and Morris 1985; Wendelaar Bonga et al. 1987; van Dijk et al. 1993). Thus, such acclimatory responses are not unique to acidophilic Amazonian fish, such as tambaqui. However, the intriguing question is what these compensatory mechanisms are and how they can overcome the ionoregulatory problems faced in waters as acidic as $\mathrm{pH}$ 3.5. The fact that net $\mathrm{Na}^{+}$fluxes in tambaqui were substantially positive immediately after returning to $\mathrm{pH}$ 6 suggests that $\mathrm{Na}^{+}$uptake had been up-regulated and/or that $\mathrm{Na}^{+}$efflux had been down-regulated during the previous acid exposure. Both seem likely strategies on the basis of the experiments of Gonzalez (1996) and Gonzalez et al. (1997) using various species of tetra as model acidophilic Amazon species. From these studies, it is apparent that neon tetras can restore $\mathrm{Na}^{+}$balance within $24 \mathrm{~h}$ of being exposed to $\mathrm{pH} 3.5$ as a result of a rapid stimulation (almost doubling) of $\mathrm{Na}^{+}$uptake, followed by a slower recovery of $\mathrm{Na}^{+}$efflux to preexposure rates (Gonzalez 1996). How these ionoregulatory processes are affected and whether the response is similar in the other 1,000 or so species of fish native to the Rio Negro is currently unknown.

In conclusion, acid tolerance in the three cultured species investigated here was predictable based on the degree to which they would experience naturally acidic blackwater in the wild. The most tolerant of these, the tambaqui, exhibited an impressive insensitivity to low $\mathrm{pH}$ in our experiments. However, it is noteworthy that even this acid tolerance was surpassed by that observed in four species caught and assessed in Rio Negro blackwater during an expedition on board the research vessel Amanai II in November 1995 (Gonzalez et al. 1998). Future work on the ionoregulatory mechanisms in these wild Rio Negro species could be the most revealing in terms of ionoregulatory adaptations to life in ion-poor and acidic waters.

\section{Acknowledgments}

This work was supported by a research grant from the Royal Society to R.W.W., a Natural Sciences and Engineering Research Council (Canada) research grant to C.M.W., and a Centro Nacional de Pesquisas (Brazil) research grant to A.L.V. We thank Vera Almeida-Val, Maria de Nazare Paula da Silva, and all the students, staff, and faculty of Instituto Nacional de Pesquisas da Amazonia for their hospitality, enthusiasm, and support during the period of study. We are also indebted to Duct Tape 
and Leatherman for their omnipotence and to Amazonas T $\rightarrow$ McDonald D.G. 1983. The effects of $\mathrm{H}^{+}$upon the gills of freshfor Kaiserbeer and Shkuhbidoo.

\section{Literature Cited}

$\rightarrow$ Anderson D.E., S.D. Reid, T.W. Moon, and S.F. Perry. 1991. Metabolic effects associated with chronically elevated cortisol in rainbow trout (Oncorhynchus mykiss). Can J Fish Aquat Sci 48:1811-1817.

Araujo-Lima C.A.R.M. and M. Goulding. 1997. So Fruitful a Fish: Ecology, Conservation, and Aquaculture of the Amazon's Tambaqui. Columbia University Press, New York.

$\rightarrow$ Audet C., R.S. Munger, and C.M. Wood. 1988. Long-term sublethal acid exposure in rainbow trout (Salmo gairdneri) in soft water: effects on ion exchanges and blood chemistry. Can J Fish Aquat Sci 45:1387-1398.

$\rightarrow$ Brauner C. J., C.L. Ballantyne, D.J. Randall, and A.L. Val. 1995. Air breathing in the tamoatá (Hoplosternum littorale) as ar $\rightarrow$ adaptation to hypoxic, acid, and hydrogen sulphide rich waters. Can J Zool 73:739-744.

$\rightarrow$ Fromm P.O. 1980. A review of some physiological and toxicological responses of freshwater fish to acid stress. Enviror $\rightarrow$ Biol Fish 5:79-94.

Furch K. 1984. Water chemistry of the Amazon basin: the distribution of chemical elements among freshwaters. Pp. 167-199 in H. Sioli, ed. The Amazon: Limnology and Landscape Ecology of a Mighty Tropical River and Its Basin. Junk, Dordrecht.

Gonzalez R.J. 1996. Ion regulation in ion poor, acidic waters of the Rio Negro. Pp. 119-121 in A. Val, D.J. Randall, anc $\rightarrow$ D. MacKinlay, eds. The Physiology of Tropical Fish. Symposium Proceedings. American Fisheries Society, San Francisco.

$\rightarrow$ Gonzalez R.J., V.M. Dalton, and M.L. Patrick. 1997. Ion regulation in ion-poor acidic water by the blackskirt tetra ( Gymnocorymbus ternetzi), a fish native to the Amazon River. Physiol Zool 70:428-435.

$\rightarrow$ Gonzalez R.J. and W.A. Dunson. 1987. Adaptations of sodium balance to low $\mathrm{pH}$ in a sunfish (Enneacanthus obesus) from naturally acidic waters. J Comp Physiol B 157:555-566.

$\rightarrow$. 1989. Acclimation of sodium regulation to low $\mathrm{pF} \rightarrow$ and the role of calcium in the acid-tolerant sunfish Enneacanthus obesus. Physiol Zool 62:977-992.

$\rightarrow$ Gonzalez R.J., C.M. Wood, R.W. Wilson, M.J. Patrick, H.L. Bergman, A. Narahara, and A.L. Val. 1998. Effects of water $\mathrm{pH}$ and calcium concentration on ion balance in fish of the Rio Negro, Amazon. Physiol Zool 71:15-22.

Hills A.G. 1973. Acid-Base Balance: Chemistry, Physiology, Pathophysiology. Williams \& Wilkins, Baltimore.

Höbe H., C.M. Wood, and B.R. McMahon. 1984. Mechanisms of acid-base and ionoregulation in white suckers (Catostomus commersoni) in natural soft water. 1. Acute exposure to low ambient pH. J Comp Physiol A 154:35-46. water fish. Can J Zool 61:691-703.

McDonald D.G. and C.M. Wood. 1981. Branchial and renal acid and ion fluxes in the rainbow trout, Salmo gairdneri, at low environmental pH. J Exp Biol 93:101-118.

Nemenyi P., S.K. Dickson, N.B. White, and M.L. Hedstrom. 1977. Statistics from Scratch. Holden-Day, San Francisco.

Reid S.D. 1995. Adaptation to and effects of acid water on the fish gill. Pp. 213-227 in P.W. Hochachka and T.P. Mommsen, eds. Biochemistry and Molecular Biology of Fishes. Vol. 5. Elsevier, Amsterdam.

$\rightarrow$ Stuart S. and R. Morris. 1985. The effects of season and exposure to reduced $\mathrm{pH}$ (abrupt and gradual) on some physiological parameters in brown trout (Salmo trutta). Can J Zool 63:1078-1083.

Val A.L. and V.M.F. Almeida-Val. 1995. Fishes of the Amazon and Their Environment. Springer, Berlin.

van der Boon J., G.E.E.J.M. van den Thillart, and A.D.F. Addink. 1991. The effects of cortisol administration on intermediary metabolism in teleost fish. Comp Biochem Physiol 100A:47-53.

van Dijk P.L.M., G.E.E.J.M. van den Thillart, P. Balm, and S. Wendelaar Bonga. 1993. The influence of gradual water acidification on the acid-base status of plasma hormone levels in carp. J Fish Biol 42:661-671.

Verbost P.M., F.P.J.G. Lafeber, F.A.T. Spanings, E.M. Aarden, and S.E.W. Bonga. 1992. Inhibition of $\mathrm{Ca}^{2+}$ uptake in freshwater carp, Cyprinus carpio, during short-term exposure to aluminum. J Exp Biol 262:247-254.

Verdouw H., C.J.A. van Echteld, and E.M.J. Dekkers. 1978. Ammonia determinations based on indophenol formation with sodium salicylate. Water Res 12:399-402.

Walker I. and P.A. Henderson. 1996. Ecophysiological aspects of Amazonian blackwater litterbank fish communities. Pp. 7-22 in A.L. Val, V.M.F. Almeida-Val, and D.J. Randall, eds. Physiology and Biochemistry of Fishes of the Amazon. Instituto Nacional de Pesquisas da Amazonia, Manaus.

Wendelaar Bonga S.E., G. Flik, and P.H.M. Balm. 1987. Physiological adaptation to acid stress in fish. Ann Soc R Zool Belg 117:243-254.

Wilson R.W., H.L. Bergman, and C.M. Wood. 1994. Metabolic costs and physiological consequences of acclimation to aluminum in juvenile rainbow trout (Oncorhynchus mykiss). 1. Resting physiology, acclimation specificity, feeding and growth. Can J Fish Aquat Sci 51:527-535.

Wood C.M. 1989. The physiological problems of fish in acid waters. Pp. 125-152 in R. Morris, E.W. Taylor, D.J.A. Brown, and J.A. Brown, eds. Acid toxicity and aquatic animals. Cambridge University Press, Cambridge.

Wood C.M. and G.G. Goss. 1990. Kinetic analysis of the relationships between ion exchange and acid-base regulation at the gills of freshwater fish. Pp. 119-136 in J.-P. Truchot and B. Lalhou, eds. Animal Nutrition and Transport Pro- 
cesses. 2. Transport, Respiration and Excretion: Comparative and Environmental Aspects. Comparative Physiology. Vol. 6. Karger, Basel.

Wood C.M. and D.G. McDonald. 1982. Physiological mecha nisms of acid toxicity to fish. Pp.197-226 in R.E. Johnson, ed. Acid Rain/Fisheries: Proceedings of an International Symposium on Acidic Precipitation and Fishery Impacts in North-Eastern North America. American Fisheries Society, Bethesda, Md.

$\rightarrow$ Wood C.M., R.W. Wilson, R.J. Gonzalez, M.L. Patrick, H.L.
Bergman, A. Narahara, and A.L. Val. 1998. Responses of an Amazonian teleost, the tambaqui (Colossoma macropomum), to low pH in extremely soft water. Physiol Zool 71:658-670.

Zall D.M., M.D. Fisher, and Q.M. Garner. 1956. Photometric determination of chloride in water. Anal Chem 28: 1665-1678.

Zanibon-Filho E. 1985. Biologia e Reproduço de Matrincha, Brycon cephalus (Gunther, 1869) (Teleostei, Characidae). MS thesis. Instituto Nacional de Pesquisas da Amazonia/Universidade Federal do Amazonas. 